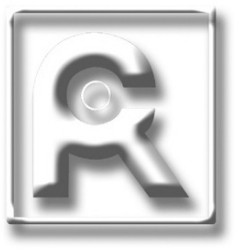

\title{
Los editoriales de la Revista Colombiana de Radiología
}

Con ocasión de los 75 años de la Asociación Colombiana de Radiología, y por invitación del Comité Científico, les dimos una mirada a los editoriales que se han publicado en la Revista Colombiana de Radiología.

Además de los editores en jefe y asociados, han participado como invitados radiólogos colombianos y extranjeros. Los primeros editoriales fueron escritos por Santiago Restrepo Uribe, primer director de la revista. Los editores asociados, los radiólogos Carlos Jiménez Cuervo y Luis Felipe Uriza Carrasco, también han participado con editoriales, al igual que otros miembros del Comité Editorial. Cuando Rodrigo Restrepo, Mauricio Lozano, Martha Edith Oyuela y Federico Lubinus eran presidentes de la Asociación Colombiana de Radiología, también fueron editores invitados. Así mismo, los jefes de los programas académicos de radiología o de instituciones académicas que lideraron las ediciones especiales con la producción científica de sus departamentos escribieron los editoriales correspondientes. Entre los radiólogos extranjeros que han sido nuestros invitados, destaco a Mauricio Castillo, quien fue autor de tres editoriales sobre el agotamiento de los médicos en radiología, y a José Luis del Cura.

Los editoriales que incluyen reflexiones para los radiólogos y aquellos que invitan a escribir para publicar son los más numerosos, y suman un poco mas de la mitad de los publicados hasta la fecha.

Las funciones de los editoriales en las revistas médicas son variadas. Como en otras publicaciones, algunos pretenden mostrar la posición de la revista hacia temas de interés o controversia y así ha sido con los que denominamos "reflexiones para los radiólogos". En ellos se han tratado temas como la influencia de las nuevas tecnologías y los avances en la práctica de los médicos radiólogos.

$\mathrm{Su}$ trascendencia también ha sido variada. Algunos han señalado cambios fundamentales y podríamos decir que siguen siendo actuales, como "El papel del radiólogo en el infarto cerebral en el siglo XXI" - que apoyaba lo expuesto en el artículo "Evaluación de la perfusión cerebral"-, "La contribución de las imágenes en el trauma craneoencefálico" y "Tamizaje de cáncer de seno en países del tercer mundo". Otros editoriales, por el contrario, señalaron hechos que no trascendieron tanto, como "Qué lugar ocupamos hoy los radiólogos en el diagnóstico del cáncer gástrico", que fomentaba el diagnóstico de la patología gástrica mediante el examen baritado de vías digestivas, cuyo papel en la práctica médica hoy es marginal.

Desde los editoriales también se ha invitado a los radiólogos a reflexionar sobre temas que influyen en su trabajo diario, de forma paralela a lo puramente científico: la calidad de las imágenes, el consentimiento informado, el control de la radiación en estudios de escanografía, la seguridad en resonancia magnética, y los radiólogos y su relación con el paciente.
La autonomía profesional del médico, las batallas territoriales, la virtud de reconocer el valor de aquellas cosas buenas que nos rodean y el agotamiento en los médicos radiólogos son ejemplos de temas que han motivado a los radiólogos colombianos sobre asuntos que trascienden de lo puramente radiológico a su ser como médico y como persona.

Un grupo importante de los editoriales de la Revista Colombiana de Radiología trata de animar a los radiólogos a publicar, destacando la importancia de plasmar sus producciones científicas en un escrito. También en esta área se han descrito las reglas de publicación, de redacción y hasta de ortografía. Algunos de los escritos en este sentido se han titulado “¿Por qué no escribimos?”, “Escribir para la radiología en nuestro medio" e "Investigar, publicar y escribir en medio de la crisis". La crisis a la que hacía referencia ese editorial era la de finales del siglo pasado, cuando la difícil situación económica del país llevó al cierre del Instituto de Seguros Sociales y de centros tan importantes como el Hospital Infantil Lorencita Villegas de Santos.

Otros de los títulos de editoriales relacionados con escribir y publicar han sido: "Conceptos sobre autoría", "La investigación en radiología", "La calidad en las publicaciones científicas", "La calidad y visibilidad de una publicación científica", y "El consentimiento informado de los pacientes para la publicación de fotografías médicas".

La educación en radiología como función de la revista ha sido un contenido destacado, como se puede ver en los números dedicados a los departamentos académicos de radiología e imágenes diagnósticas, cuyos editoriales fueron escritos por los responsables de dicha educación en radiología para aquella época. "El reto de enseñar radiología e imágenes diagnósticas", "El informe radiológico estructurado", y "Comparar, una gran herramienta de diagnóstico" han sido editoriales orientados a la educación.

Los editoriales informativos han anunciado algunas de las trasformaciones de la Asociación Colombiana de Radiología, sus alianzas y sus aniversarios. Por supuesto, también se ha comunicado mediante editoriales el estado de la revista en cuanto a su indexación y las relaciones con Publindex, el sistema de Colciencias para la evaluación y clasificación de las revistas científicas nacionales.

Quise, entonces, compartir mediante este editorial la mirada hacia atrás de la página editorial que se encuentra en cada número de la revista, la cual informa, invita a reflexionar o a publicar y presenta su posición ante temas que considera de interés general para los radiólogos como profesionales médicos y como personas.

Sonia Bermúdez Muñoz, M. D.

Editora

revcolradiologia@gmail.com 